\title{
Pathogenesis of systemic lupus erythematosus
}

C C Mok and C S Lau

J. Clin. Pathol. 2003;56;481-490

doi:10.1136/jcp.56.7.481

Updated information and services can be found at:

http://jcp.bmj.com/cgi/content/full/56/7/481

These include:

References This article cites 146 articles, 40 of which can be accessed free at: http://jcp.bmj.com/cgi/content/full/56/7/481\#BIBL

18 online articles that cite this article can be accessed at: http://jcp.bmj.com/cgi/content/full/56/7/481\#otherarticles

Rapid responses You can respond to this article at:

http://jcp.bmj.com/cgi/eletter-submit/56/7/481

Email alerting Receive free email alerts when new articles cite this article - sign up in the box at the service top right corner of the article

Topic collections Articles on similar topics can be found in the following collections

Other Endocrinology (621 articles)

Other immunology (943 articles)

Systemic Lupus Erythematosus (224 articles)

Notes

To order reprints of this article go to:

http://www.bmjjournals.com/cgi/reprintform

To subscribe to Journal of Clinical Pathology go to:

http://www.bmjjournals.com/subscriptions/ 


\section{REVIEW}

\section{Pathogenesis of systemic lupus erythematosus}

\section{C Mok, C S Lau}

J Clin Pathol 2003;56:481-490

The exact patho-aetiology of systemic lupus erythematosus (SLE) remains elusive. An extremely complicated and multifactorial interaction among various genetic and environmental factors is probably involved. Multiple genes contribute to disease susceptibility. The interaction of sex, hormonal milieu, and the hypothalamo-pituitary-adrenal axis modifies this susceptibility and the clinical expression of the disease. Defective immune regulatory mechanisms, such as the clearance of apoptotic cells and immune complexes, are important contributors to the development of SLE. The loss of immune tolerance, increased antigenic load, excess $T$ cell help, defective $B$ cell suppression, and the shifting of Thelper 1 (Th 1 ) to Th2 immune responses leads to $B$ cell hyperactivity and the production of pathogenic autoantibodies. Finally, certain environmental factors are probably required to trigger the disease.

See end of article for authors' affiliations

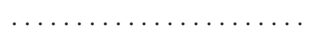

Correspondence to: Dr C C Mok, Department of Medicine and Geriatrics, Tuen Mun Hospital, Tsing Chung Koon Road, New

Territories, Hong Kong; ccmok@netvigator.com

Accepted for publication 12 February 2003
Ystemic lupus erythematosus (SLE) is a prototypic autoimmune disease characterised by the production of antibodies to components of the cell nucleus in association with a diverse array of clinical manifestations. The primary pathological findings in patients with SLE are those of inflammation, vasculitis, immune complex deposition, and vasculopathy. The exact aetiology of SLE is unknown. SLE shows a strong familial aggregation, with a much higher frequency among first degree relatives of patients. Moreover, in extended families, SLE may coexist with other organ specific autoimmune diseases such as haemolytic anaemia, immune thrombocytopenic purpura, and thyroiditis. The concordance of the disease in identical twins is approximately $25-50 \%$ and that in dizygotic twins is around 5\%. ${ }^{1}$ This suggests that genetic factors play an important role in the predisposition of the disease. However, most cases of SLE are sporadic without identifiable genetic predisposing factors, suggesting that multiple environmental or yet unknown factors may also be responsible.

\section{GENETIC SUSCEPTIBILITY}

The concordance of SLE in identical twins, the increase in frequency of SLE among first degree relatives, and the increased risk of developing the disease in siblings of SLE patients reflects a polygenic inheritance of the disease. Many different genes contribute to disease susceptibility. In a small proportion of patients $(<5 \%)$, a single gene may be responsible. For instance, patients with homozygous deficiencies of the early components of complement are at risk of developing SLE or a lupus-like disease. ${ }^{2}$ For most of the remaining patients, multiple genes are required. It is estimated that at least four susceptibility genes are needed for the development of the disease. ${ }^{3}$

Of the genetic elements, the genes of the major histocompatibility complex (MHC) have been most extensively studied for their contribution to human SLE. Population studies reveal that the susceptibility to SLE involves human leucocyte antigen (HLA) class II gene polymorphisms. An association of HLA DR2 and DR3 with SLE is a common finding in patients of different ethnicities, with a relative risk for the development of disease of approximately two to five. ${ }^{1}$ The HLA class II genes have also been associated with the presence of certain autoantibodies such as anti-Sm (small nuclear ribonuclear protein), anti-Ro, anti-La, anti-nRNP (nuclear ribonuclear protein), and anti-DNA antibodies. ${ }^{3}$

"It is estimated that at least four susceptibility genes are needed for the development of the disease"

Among other MHC gene systems, inherited complement deficiencies also influence disease susceptibility. The HLA class III genes, particularly those encoding complement components C2 and C4, confer risk for SLE in certain ethnic groups. Patients with homozygous C4A null alleles, irrespective of the ethnic background, are at high risk of developing SLE. Moreover, SLE is associated with inherited deficiencies of $\mathrm{Clq}$, $\mathrm{C} 1 \mathrm{r} / \mathrm{s}$, and $\mathrm{C} 2 .{ }^{4} \mathrm{~A}$ decrease in complement activity could promote disease susceptibility by impairing the neutralisation and clearance of self and foreign antigens. When the antigen burden overwhelms the clearance capacity of the immune system, autoimmunity may ensue.

In addition, many polymorphic non-MHC genes have been reported to be associated with

Abbreviations: APC, antigen presenting cell; CD40L, CD40 ligand; $\mathrm{CRH}$, corticotrophin releasing hormone; DHEA, dehydroepiandrosterone; dsDNA, double stranded DNA; FasL, Fas ligand; GnRH, gonadotrophin releasing hormone; HLA, human leucocyte antigen; HPA, hypothalamo-pituitary-adrenal; HRT, hormonal replacement therapy; IL, interleukin; $\mathrm{LH}$, luteinising hormone; MBP, mannose binding protein; $M H C$, major histocompatibility complex; NK, natural killer; nRNP, nuclear ribonuclear protein; $O C$, oral contraceptive; PBMC, peripheral blood mononuclear cell; SLE, systemic lupus erythematosus; sm, Smith antigen; snRPN, small nuclear ribonuclear protein; Th 1, T helper type 1 


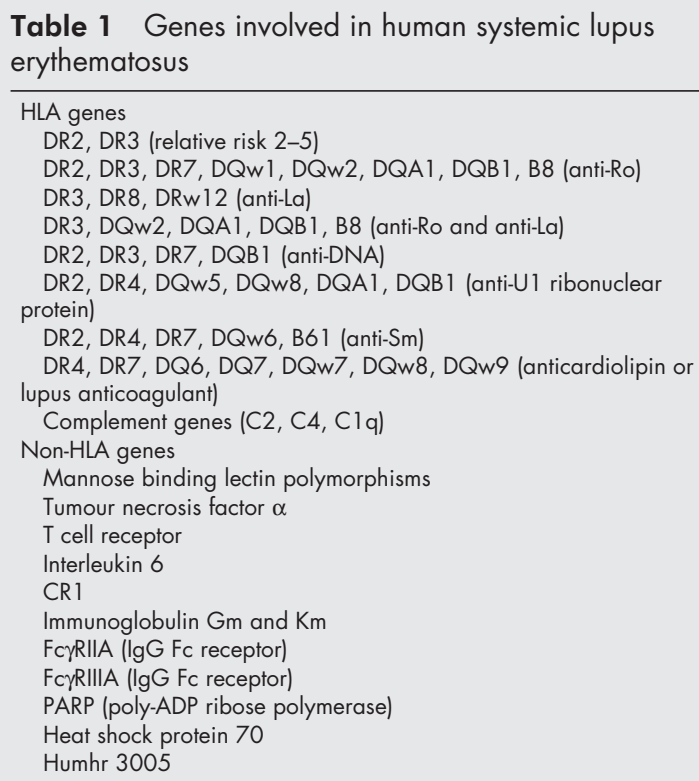

Table 1 Genes involved in human systemic lupus erythematosus

SLE. These include genes that encode mannose binding protein (MBP), tumour necrosis factor $\alpha$, the T cell receptor, interleukin 6 (IL-6), CRl, immunoglobulin Gm and Km allotypes, FcyRIIA and FcyRIIIA (both IgG Fc receptors), and heat shock protein $70 .{ }^{35}$ However, in most cases, consistent results could not be obtained in subsequent studies in different ethnic groups. Some of these polymorphic genes may confer risk to certain subsets of patients with SLE. For instance, the FcyRIIA polymorphism has been associated with nephritis in African Americans and Koreans, ${ }^{67}$ and the Fc $\gamma$ RIIIA polymorphism with SLE in Hispanics and white populations. ${ }^{89}$ In addition, mutations of codon 54 of the MBL gene carry a minor risk for SLE susceptibility in southern Chinese. ${ }^{10}$

During the past few years, linkage analyses using SLE multiplex families have provided many chromosomal regions for further exploration of susceptibility genes. ${ }^{11-14}$ Six regions exhibiting significant linkage to SLE are promising. Studies are under way to fine map these linked regions and to identify the genes in the susceptibility regions. The discovery of multiple chromosome regions conferring risk for SLE development supports the notion that SLE is a polygenic disease. Table 1 summarises the genes that are involved in human SLE.

\section{SEX, HORMONES, AND THE HYPOTHALAMO- PITUITARY-ADRENAL AXIS}

SLE is predominantly a female disease..$^{15}$ First onset of SLE before puberty and after menopause ${ }^{16}$ is uncommon. The female predilection becomes less pronounced outside the reproductive age range. In addition, patients with Klinefelter's syndrome, characterised by hypergonadotrophic hypogonadism, are prone to the development of SLE. ${ }^{17}$ These observations suggest a role for endogenous sex hormones in disease predisposition.

Abnormal oestrogen metabolism has been demonstrated in patients with SLE of both sexes, with an increase in $16 \alpha$ hydroxylation of oestrone, resulting in significantly raised $16 \alpha$ hydroxyestrone concentrations. ${ }^{18}$ The $16 \alpha$ metabolites are more potent and feminising oestrogens. Women with SLE also have low plasma androgens, including testosterone, dihydrotestosterone, dehydroepiandrosterone (DHEA), and dehydroepiandrosterone sulfate. ${ }^{19}{ }^{20}$ This abnormality might be explained by increased testosterone oxidation at $\mathrm{C}-17^{21}$ or increased tissue aromatase activity. ${ }^{22}$ The concentrations of androgens correlate inversely with disease activity. ${ }^{20}$ Low concentrations of plasma testosterone and raised luteinising hormone ( $\mathrm{LH}$ ) values ${ }^{23}{ }^{24}$ have been found in some men with SLE. Thus, excessive oestrogenic but inadequate androgenic hormonal activity in both men and women with SLE might be responsible for the alteration of the immune responses.

Table 2 summarises the actions of oestrogens on various cell types of the immune system. Both physiological and supraphysiological concentrations of oestrogens facilitate humoral responses, leading to increased B cell proliferation and antibody production. ${ }^{25-28}$ On the contrary, high doses of oestrogens inhibit $\mathrm{T}$ cell responses, such as proliferation and IL-2 production..$^{29}$ Oestrogens also increase calcineurin mRNA levels and enhance the cell surface expression of CD40 ligand (CD40L) in cultured T cells from patients with SLE. ${ }^{31}$ These effects appear to be unique to patients with SLE, indicating that lupus $\mathrm{T}$ cells are more sensitive to oestrogens. Taken together, oestrogens may aggravate SLE by prolonging the survival of autoimmune cells, increasing $T$ helper type 2 (Th2) cytokine production, and stimulating B cells to produce autoantibodies. The inhibition of the Thl response and the enhancement of CD40L expression on lupus T cells may indirectly promote the Th2 response and lead to further B cell hyperactivity.

The effect of androgens on lymphocyte functions has been less well studied. Testosterone reduces immunoglobulin production from peripheral blood mononuclear cells of both normal subjects and patients with SLE. ${ }^{33}$ DHEA has been shown to be associated with enhancement of Thl and inhibition of Th2 immune responses in both humans and mice..$^{35} 36$

Table 2 Effects of oestrogen on immune function ${ }^{25-30}$

\begin{tabular}{|c|c|c|}
\hline Cell type & Effect & Dose \\
\hline \multirow[t]{2}{*}{ B cells } & $\begin{array}{l}\uparrow B \text { cell differentiation and in vitro Ig production including anti-dsDNA (patients with SLE and } \\
\text { healthy subjects) }\end{array}$ & Physiological \\
\hline & $\downarrow \ln$ vitro apoptosis of PBMCs and $\downarrow T N F$ - $\alpha$ production (patients with SLE, not in healthy subjects) & Physiological \\
\hline \multirow[t]{4}{*}{ T cells } & $\downarrow$ Proliferative response to mitogens and antigens & High \\
\hline & LIL-2R expression and IL-2 production in activated peripheral blood T cells (healthy subjects) & High \\
\hline & $\begin{array}{l}\uparrow \text { Calcineurin mRNA values in cultured T cells (patients with SLE, not in healthy controls or patients } \\
\text { with other rheumatic diseases) }\end{array}$ & Dose dependent \\
\hline & $\uparrow C D 40 L$ expression of peripheral blood T cell (patients with SLE, not in healthy controls) & Physiological \\
\hline Monocytes & $\begin{array}{l}\text { TIL-10 production (patients with SLE and healthy subjects) } \\
\uparrow c N O S \text { release }\end{array}$ & $\begin{array}{l}\text { Physiological } \\
\text { Physiological }\end{array}$ \\
\hline Others & $\uparrow$ Adhesion molecule expression in endothelial cells & High \\
\hline
\end{tabular}

CD40L, CD40 ligand; cNOS, cyłoplasmic nitric oxide synthase; dsDNA, double stranded DNA; Ig, immunoglobulin; IL, interleukin; IL-2R, interleukin 2 receptor; PMBC, peripheral blood mononuclear cells; SLE, systemic lupus erythematosus; TNF- $\alpha$, tumour necrosis factor $\alpha$. 
Table 3 Role of hormones in human SLE

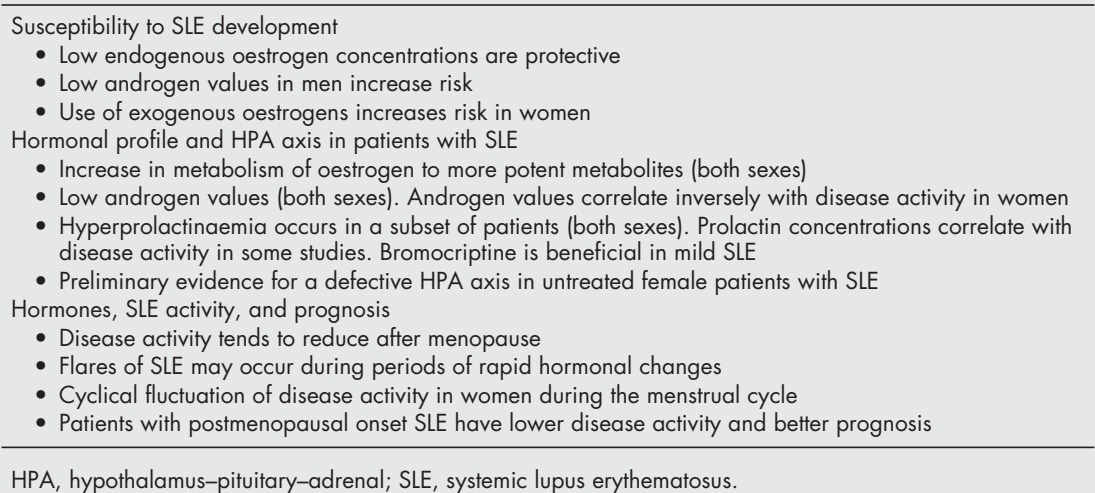

The opposite effects of oestrogens and androgens on the immune system, coupled with unbalanced oestrogenic and androgenic hormonal activity in patients with SLE, may help explain some of the immune aberrations seen in this disease.

Epidemiological studies reveal an association between the use of exogenous oestrogens and the onset of SLE. In a large cohort of nurses as part of the Nurses' Health Study, it was shown that both the past use of oral contraceptive (OC) pills and hormonal replacement therapy (HRT) was associated with a slightly increased risk of SLE development. ${ }^{37} 38$ Moreover, a proportional increase in the risk of SLE related to the duration of HRT was seen. A more recent case-control study also reported an increased risk of the development of SLE or discoid lupus in women receiving HRT for more than two years when compared with non-users. ${ }^{39}$

There is evidence that endogenous oestrogen concentrations may influence disease activity and prognosis in human SLE. In the presteroid era, improvement of SLE was noted in individual patients who had undergone menopause or oophorectomy. ${ }^{40}$ Flares of SLE are well known to occur during periods of rapid hormonal changes. These include pregnancy, puerperium, ovulation stimulation during in vitro fertilisation, and exogenous oestrogen administration. ${ }^{41-44}$ Lupus activity tends to be reduced when patients undergo menopause. ${ }^{45}$ It has also been noted that in many women disease flares are more common during the second half of the menstrual cycle, after the midcycle surge of oestrogen. ${ }^{46}$ The administration of exogenous oestrogens in the form of OC pills and HRT may exacerbate the disease in patients with existing lupus. ${ }^{47-49}$ Furthermore, late onset SLE, defined as first onset of disease after the age of 50, was reported have a more benign disease course, with less serious organ involvement. ${ }^{50}$ Patients with SLE who have low female sex hormone values at disease onset were found to have a lower relative mortality risk when compared with age matched controls. ${ }^{51}$

Prolactin has recently been found to be an immunostimulatory hormone..$^{52}$ The main origin is the anterior pituitary, but lymphocytes are also capable of producing prolactin, which serves as an autocrine or paracrine mediator. ${ }^{53}$ Chronic hyperprolactinaemia induced by syngeneic pituitary gland implantation stimulates primary humoral antibody responses in rats, $^{54}$ and accelerates autoimmune phenomena in lupus prone mice. ${ }^{55}$ Recent data suggest that the stimulatory actions of oestrogens on autoreactive $\mathrm{B}$ cells require the presence of prolactin. ${ }^{56}$

Hyperprolactinaemia has been demonstrated in a proportion of patients with SLE of both sexes. ${ }^{57-64}$ Prolactin concentrations correlate with disease activity in some studies. ${ }^{58}{ }^{64}$ Bromocriptine, a dopamine agonist that selectively inhibits prolactin secretion from the pituitary, has been shown to be useful in the treatment of non-life threatening SLE. ${ }^{65} 66$ However, the exact role of prolactin in SLE requires further work because a positive correlation between lupus activity and prolactin values cannot be demonstrated consistently. ${ }^{59}{ }^{62-64}$

\section{"There is evidence that endogenous oestrogen concentrations may influence disease activity and prognosis in human systemic lupus erythematosus"}

Gonadotrophin releasing hormone (GnRH), a decapeptide produced by the hypothalamus, regulates the release of LH and follicle stimulating hormone from the anterior pituitary. Recent animal studies show that GnRH is immunostimulatory. ${ }^{67}$ In lupus prone mice, GnRH has been shown to exacerbate lupus, but the effect appears to be sexually dimorphic. ${ }^{68}{ }^{69}$ However, the role of GnRH in human SLE requires further evaluation.

The hypothalamo-pituitary-adrenal (HPA) axis is the chief component of the stress system. The stress induced increase in serum concentrations of glucocorticoids is essential for the prevention of autoreactive or unrestrained amplification of the immune response, which results in self injury and autoimmunity. A defective HPA axis may confer susceptibility to autoimmune disorders. Female Lewis (LEW/N) rats, characterised by a defective hypothalamic corticotrophin releasing hormone (CRH) response to several immunological activators, including IL- $1,{ }^{70}$ are highly susceptible to a wide variety of experimental autoimmune disorders.

There is preliminary evidence that a defective HPA axis is present in both murine and human lupus. A significantly lower increase in plasma corticosterone concentrations upon stimulation by recombinant IL- 1 is seen in lupus prone (MRL/ lpr) mice. ${ }^{71}$ Aging of MRL/lpr mice, which is accompanied by an increase in autoantibody production, is associated with a decrease in hypothalamic CRH mRNA expression. ${ }^{72}$ Studies on the function of the HPA axis in patients with SLE are limited and often confounded by the effect of concomitant glucocorticoid treatment. A study on a group of active untreated female patients with SLE reports that the cortisol response to induced hypoglycaemia is significantly lower in patients than in healthy controls, indicating that some degree of HPA axis dysfunction does exist. ${ }^{73}$ The dysregulated HPA axis in SLE may be responsible for disease susceptibility and progression.

Table 3 summarises the role of hormones in the pathogenesis of SLE. Hormones may not have a direct causative role in SLE, but a milieu consisting of different values of hypothalamo-pituitary and gonadal hormones may create an endogenous environment for susceptible individuals to develop the disease. Changes in the concentrations of sex steroids, coupled with certain yet undiscovered environmental factors, may lead to disease flares and serve to explain the "wax and wane" nature of the disease. 


\section{IMMUNOPATHOLOGY}

The basic pathological features of SLE are that of inflammation and blood vessel abnormalities, which include band or occlusive vasculopathy, vasculitis, and immune complex deposition. The best characterised organ pathology is in the kidney. By light and immunofluorescence microscopy, renal biopsies in patients with SLE display mesangial cell proliferation, inflammation, basement membrane abnormalities, and immune complex deposition, comprising immunoglobulins and complement components. On electron microscopy, these deposits can be visualised in the mesangium and the subendothelial or subepithelial surface of the basement membrane.

Other organ systems affected by SLE usually display non-specific inflammation or vascular abnormalities, although pathological findings are sometimes minimal. One example is cortical microinfarcts and bland vasculopathy with degenerative or proliferative changes in patients with central nervous system disease. Inflammation and necrotising vasculitis can rarely be found. Occlusive vasculopathy is a common histological feature associated with the presence of antiphospholipid antibodies. Atherosclerosis and tissue damage caused by hypertension, corticosteroids, and other drugs can be demonstrated in patients with long standing SLE.

\section{Autoantibodies}

The central immunological disturbance in patients with SLE is autoantibody production. These antibodies are directed at several self molecules found in the nucleus, cytoplasm, and cell surface, in addition to soluble molecules such as IgG and coagulation factors. Antinuclear antibodies are most characteristic and present in more than $95 \%$ of patients. Anti-double stranded DNA (ds-DNA) and anti-Sm antibodies are unique to patients with SLE. In fact, their presence is included in the classification criteria of SLE. ${ }^{74}$ The Sm antigen is designated as a small nuclear ribonucleoprotein ( $\mathrm{snRNP}$ ) and is composed of a unique set of uridine rich RNA molecules bound to a common group of core proteins and other proteins associated with the RNA molecules. Anti-Sm antibodies react with snRNP core proteins, whereas anti-DNA antibodies bind to a conserved nucleic acid determinant widely present on DNA. Anti-DNA antibody titres frequently vary over time and disease activity but anti-Sm antibody titres are usually constant.

The most remarkable feature of anti-DNA antibodies is their association with glomerulonephritis. Anti-DNA antibodies can be isolated in an enriched form from glomerular eluates of patients with active lupus nephritis and anti-DNA antibodies can induce nephritis in normal and severe combined immunodeficient mice. ${ }^{75}{ }^{76}$ However, the correlation between anti-DNA antibodies and lupus nephritis in not complete because some patients with active nephritis are negative for anti-DNA antibodies, whereas some patients with persistent high titres of anti-DNA may not show renal involvement.

\section{"The most remarkable feature of anti-DNA antibodies is their association with glomerulonephritis"}

Anti-DNA antibodies differ in their properties, including isotype, ability to fix complement, and capacity to bind to the glomeruli causing pathogenicity. ${ }^{75}$ Only certain types of anti-DNA antibodies are pathogenic. ${ }^{77}$ The involvement of anti-DNA antibodies in lupus nephritis is suggested by several pieces of circumstantial evidence. First, clinical observations in most patients indicate that active nephritis is associated with raised anti-DNA titres and reduced total haemolytic complement values. ${ }^{78}$ Second, anti-DNA antibodies show preferential deposition in the kidneys, suggesting that DNA-anti-DNA antibody immune complexes are the main mediators of inflammation. ${ }^{79}$ Although renal injury may result from immune complexes containing anti-DNA antibodies, circulating immune complexes have been difficult to characterise because of their low concentration in serum. The formation of immune complexes in situ, instead of within the circulation, may be another possibility. Anti-DNA antibodies may bind to pieces of DNA adherent to the glomerular basement membrane via the histones or interact with additional glomerular antigens, such as Clq, nucleosomes, heparan sulfate, and laminin. ${ }^{80}$ The binding of anti-DNA antibodies to these antigens may initiate local inflammation and complement activation, and may also anchor immune complexes to the kidney sites, whether or not they are formed in the circulation or in situ.

Although an association between certain clinical features of SLE and autoantibodies such as anti-ribosomal $\mathrm{P}$ antibodies and psychosis, and anti-Ro antibodies and congenital heart block and subacute cutaneous lupus, has been well documented, the pathogenicity of these antibodies has not been adequately studied. The exact immunological mechanisms for injury remain to be elucidated. The pathogenesis of manifestations other than glomerulonephritis is less well understood, although immune complex deposition with activation of complement at relevant sites is a probable mechanism. This is demonstrated by the frequent association of hypocomplementaemia and signs of vasculitis at the sites of active SLE. Direct antibody mediated damage and cell mediated cytotoxicity on target tissues are other possible mechanisms.

\section{Disturbances of the immune response}

SLE is characterised by a myriad of immune system aberrations that involve $\mathrm{B}$ cells, $\mathrm{T}$ cells, and cells of the monocytic lineage, resulting in polyclonal B cell activation, increased numbers of antibody producing cells, hypergammaglobulinaemia, autoantibody production, and immune complex formation. It appears that excessive and uncontrolled $\mathrm{T}$ cell help in the differentiation and activation of autoantibody forming B cells is probably a final common pathway.

The activation of $\mathrm{B}$ and $\mathrm{T}$ cells requires stimulation by specific antigens. Irritating chemicals such as pristine, bacterial DNA and cell wall phospholipids, and viral antigens can induce anti-DNA antibodies in mice. ${ }^{77}$ Moreover, self antigens, such as DNA-protein and RNA-protein complexes may induce autoantibody production. ${ }^{81}$ Environmental antigens and self antigens are taken up by professional antigen presenting cells (APCs) or bind to induced antibodies on the surface of B cells. Both professional APCs and B cells process the antigens into peptides and present them to T cells through their surface HLA molecules. The activated T cells in turn stimulate the B cells to produce pathogenic autoantibodies. In addition to contact stimulation, the interaction of $\mathrm{B}$ and $\mathrm{T}$ cells is facilitated by several cytokines, such as IL-10, and requires accessory molecules such as those of the CD40/CD40L and B7/CD28/CTLA-4 systems to initiate a second signal.

"The number of B cells at all stages of activation is increased in the peripheral blood of patients with active systemic lupus erythematosus"

B cell activation is abnormal in patients with SLE. The number of B cells at all stages of activation is increased in the peripheral blood of patients with active SLE. ${ }^{82}$ These B cell abnormalities can precede the development of SLE. Activated lupus B cells have higher intracytoplasmic calcium responses than controls. ${ }^{83}$ There is also evidence that B cells in patients with SLE are more sensitive to the stimulatory effects of cytokines such as IL-6 than non-SLE B cells. ${ }^{84}$ Moreover, the phenomenon of epitope spreading has been demonstrated in both human and murine SLE. ${ }^{85}$ Thus, it appears that B cells in patients with SLE are more prone to polyclonal activation by antigens, cytokines, and other stimuli. 


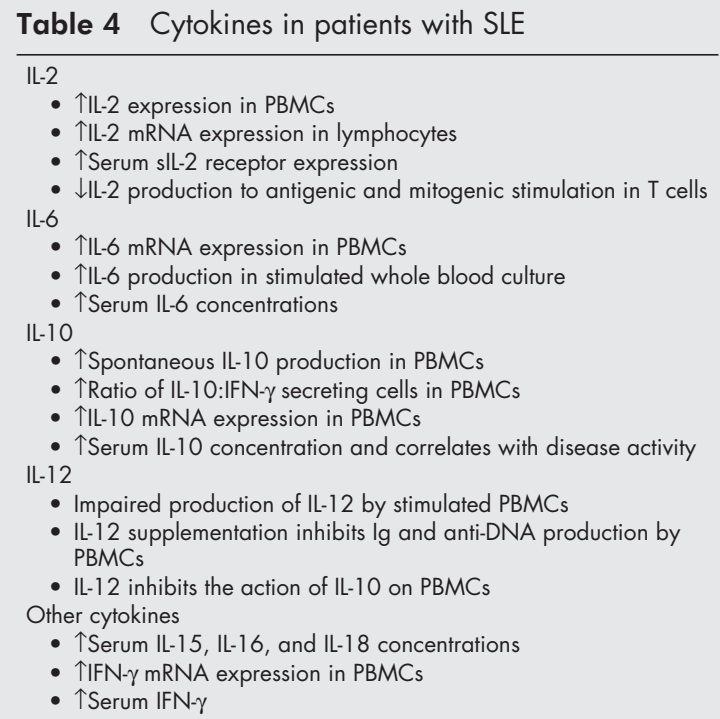

IFN, interferon; Ig, immunoglobulin; IL, interleukin; PBMC, peripheral blood mononuclear cell; slL-2, soluble interleukin 2; SLE, systemic lupus erythematosus.

Abnormalities in $\mathrm{T}$ cell function are also evident in patients with SLE. The total number of peripheral blood T cells is usually reduced, probably because of the effects of antilymphocyte antibodies. ${ }^{86}$ There is a skewing of T cell function towards B cell help, leading to enhanced antibody production. ${ }^{87}$ Experiments have shown that the early events of $\mathrm{T}$ cell activation are defective in patients with SLE compared with controls. ${ }^{88}{ }^{89}$ Although peripheral lupus $\mathrm{T}$ cells are activated, both their capacity for proliferation in response to mitogenic stimulation and IL-2 production are reduced. ${ }^{90-93}$ The reasons for the defective Thl responses in SLE remain speculative. Downregulation by excessive Th2 cytokines, defective interaction between APCs and T cells, the suppressive effects of CD8 + T cells and natural killer (NK) cells, the presence of IL-2 inhibitors, and the downregulation of IL-2 receptors are possible mechanisms. ${ }^{9495}$

\section{Cytokine network in SLE}

Cytokine profiles in patients with SLE have been studied extensively and are summarised in table 4 . Peripheral blood mononuclear cells (PBMCs) from patients with SLE proliferate less than controls when stimulated with various antigens and mitogens. ${ }^{90}$ Supernatants from phytohaemagglutinin (PHA) or autologous mixed lymphocyte reaction stimulated lupus T cells produce less IL-2 than control T cells. Lupus T cells are less responsive to IL-2 stimulation than normal $\mathrm{T}$ cells. ${ }^{91-93}$ However, the expression of IL-2 in freshly prepared SLE PBMCs was increased compared with control PBMCs. ${ }^{96}$ Lupus T cells are capable of producing normal amounts of IL-2 in response to optimal stimulation with PHA combined with phorbol esters or with anti-CD28 antibodies ${ }^{94}{ }^{97}$ As mentioned previously, the impaired in vitro IL-2 production from lupus T cells is probably the result of many factors, one of which is the downregulating effects of certain Th2 cytokines.

The recent discovery of the role played by IL-10 in the pathogenesis of SLE supports this hypothesis. IL-10 is a Th2 cytokine that acts as a potent stimulator of $\mathrm{B}$ cell proliferation and differentiation, and thereby a potential mediator of polyclonal B cell activation in SLE. Indeed, recent studies have shown that spontaneous production of IL-10 from SLE peripheral blood B cells and monocytes is significantly higher than that of controls. ${ }^{98}{ }^{99}$ The expression of IL- 10 transcripts is significantly increased in the non-T cell population of PBMCs from patients with SLE compared with controls. ${ }^{100}$ Moreover, serum IL-10 concentrations are higher in patients with SLE than in controls and are correlated with clinical and serological disease activity, and anti-DNA antibody titres. ${ }^{101-103}$ Furthermore, an increased ratio of IL-10 to interferon $\gamma$ secreting cells in the PBMCs of patients with SLE correlates with disease activity. ${ }^{104}$

The increase in IL-10 production may be a cause of the defective in vitro Thl response in lupus $\mathrm{T}$ cells. This is suggested by a study demonstrating that the addition of blocking antibodies to IL-10 significantly enhanced the proliferative response of lupus PBMCs. ${ }^{105}$ Conversely, PBMCs from patients with SLE and inactive disease cultured with IL-10 showed a significant augmentation of anti-DNA antibody production. ${ }^{106}$

IL-12, a heterodimeric cytokine produced by B cells, macrophages, and dendritic cells, promotes cell mediated immune responses but exerts some inhibitory activities on humoral responses. ${ }^{107}$ IL-12 production was found to be impaired in stimulated PBMCs from patients with SLE compared with matched controls. ${ }^{108}{ }^{109}$ The defect in IL-12 production probably lies in the monocytes but not the B cells. ${ }^{110}$ In contrast, the addition of IL-12 to lupus PBMCs significantly inhibits both spontaneous and IL-10 stimulated immunoglobulin and antiDNA antibody production. ${ }^{111}$ Moreover, the production of antiDNA antibodies by PBMCs from patients with SLE and active disease is inhibited by culturing the cells with IL-12. ${ }^{106}$ The results from these studies suggest that dysregulation of the IL-10-IL-12 balance plays a crucial role in the impaired cellular immune responses seen in patients with SLE.

\section{Defective immune regulation}

The clearing of immune complexes by phagocytic cells is defective in patients with SLE. ${ }^{7}$ This results partly from the reduced numbers of CRl receptors for complement and functional defects of the receptors on cell surfaces. ${ }^{112}{ }^{113}$ Defective clearance may also result from inadequate phagocytosis of IgG2 and IgG3 containing complexes. Allelic polymorphisms of the IgG receptors (Fc $\gamma R$ ) have recently been described. Some of the polymorphic alleles (FcyRIIA and Fc $\gamma$ RIIIA) are associated with lower binding of the Fc portions of IgG2 and IgG3, and hence impaired clearance of immune complexes. ${ }^{714}$ Indeed, the FcyRIIA and FcyRIIIA genotypes have been associated with susceptibility to SLE and nephritis in certain ethnic groups. ${ }^{7-9} 115$ Although consistent results cannot be obtained in patients of different ethnicities, impaired immune complex clearance by phagocytes is an important pathogenetic mechanism in SLE.

A recent study also demonstrated that non-inflammatory engulfment phagocytosis of apoptotic cells is impaired in patients with SLE. ${ }^{116}$ Persistently circulating apoptotic waste may serve as an immunogen for the induction of autoreactive lymphocytes and as an antigen for immune complex formation.

\section{"Impaired immune complex clearance by phagocytes is an important pathogenetic mechanism in systemic lupus erythematosus"}

The synthesis and secretion of pathogenic autoantibodies in SLE is driven by the interaction of CD4+ and CD8+ helper $\mathrm{T}$ cells, and double negative $\mathrm{T}$ cells (CD4- CD8-) with $\mathrm{B}$ cells. ${ }^{1{ }^{17}}$ Therefore, cells that normally suppress $\mathrm{B}$ cell activation, such as CD8+ suppressor T cells and NK cells are defective in their suppressive activity. It has been shown that CD8+ $\mathrm{T}$ cells and NK cells from patients with active SLE are often incapable of downregulating polyclonal immunoglobulin synthesis and autoantibody production. ${ }^{87}$ One recent study reported that $\mathrm{CD} 8+\mathrm{T}$ suppressor cell function was impaired 


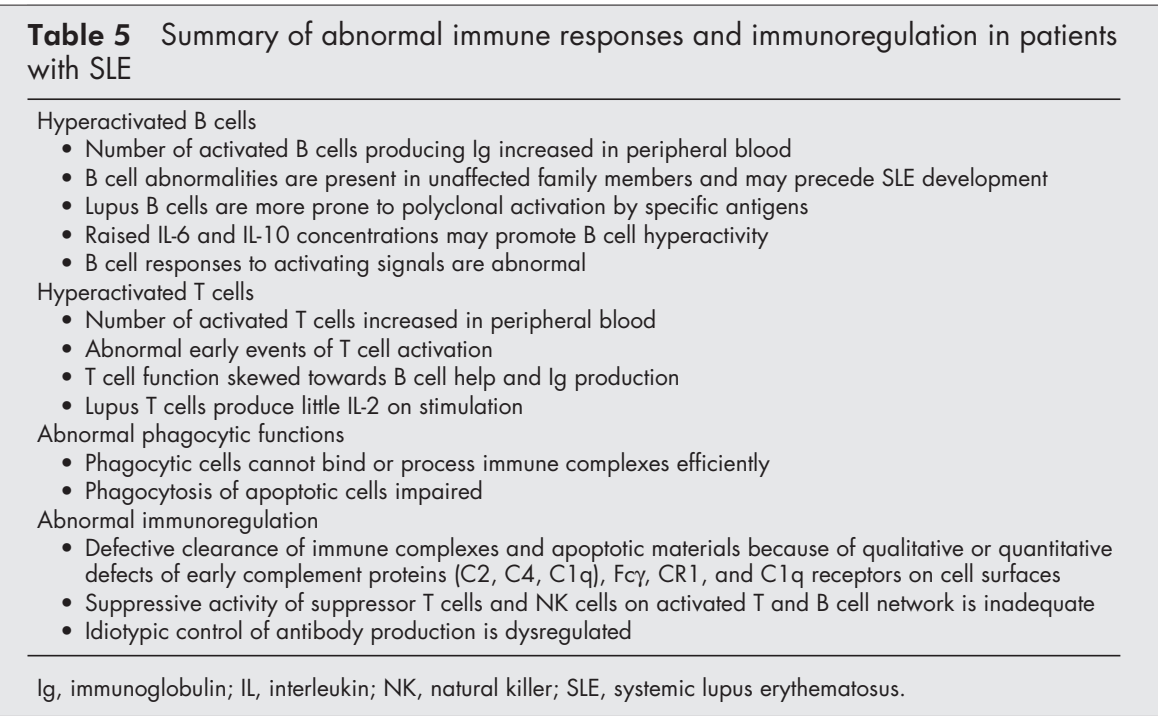

in patients with active SLE. ${ }^{118}$ This impaired suppression of $\mathrm{B}$ cells may be one factor that leads to the perpetuation of the disease.

In normal healthy subjects, overproduction of antibodies is prevented by an idiotype network. This network is probably defective in patients with SLE, leading to dysregulation of autoantibody production. ${ }^{119}$

Table 5 summarises the abnormalities in the immune response and immunoregulation in patients with SLE.

\section{APOPTOSIS AND SLE}

Apoptosis, or programmed cell death, is a process that leads to the ordered destruction of cells, avoiding the release of intracellular contents into the extracellular microenvironment, where they have a powerful inflammatory effect. Defective apoptosis leading to the prolonged survival of pathogenic lymphocytes was thought to be one disease mechanism for SLE. This hypothesis was supported by observations in murine lupus models. MRL/lpr mice are characterised by the presence of the lpr gene, which is associated with defective Fas (CD95) receptors on the surface of lymphocytes. The interaction of Fas and Fas ligand (FasL) transduces an active signal for cellular apoptosis. ${ }^{120}$ Defective Fas mediated apoptosis in MRL/lpr mice results in massive lymphoproliferation and the development of a severe lupus-like disease with immune glomerulonephritis. ${ }^{121} \mathrm{Gld} /$ gld mice, characterised by a mutation in the FasL gene leading to a non-functional FasL molecule, also develop lymphoproliferation, hypergammaglobulinaemia, and immunoglobulin deposits in the kidneys. ${ }^{122}$

However, there are several problems with this model. First, the massive lymphoproliferation resulting from defective apoptosis seen in the MRL/lpr and Gld/gld mice is not characteristic of human SLE, which conversely is often associated with profound lymphopenia. Second, the expression of both Fas and FasL is normal in patients with SLE. ${ }^{123}{ }^{124}$ Lastly, apoptosis of peripheral lymphocytes in patients with SLE has been shown to be increased compared with controls. ${ }^{125} 126$

The increased rate of apoptosis in SLE would theoretically increase the chance of leakage of intracellular antigens that may either trigger an autoimmune response or participate in the formation of immune complexes. Under normal circumstances, apoptotic cells are engulfed by macrophages in the early phase of apoptotic cell death without inducing inflammation or the immune response. Recent studies have shown that the clearance of apoptotic cells by macrophages in patients with SLE is impaired. ${ }^{116}$ This is not confined to mono- cytes and macrophages of the peripheral blood, but also occurs in the germinal centres of lymph nodes. ${ }^{127} 128$

The reasons for the defective clearance of apoptotic cells in SLE are not clear. It could be the result of quantitative or qualitative defects of the early complement proteins, such as $\mathrm{C} 2$, C4, or C1q. Patients with homozygous deficiencies in these complement components develop a severe lupus-like disease early in life. ${ }^{129}$ The Clq receptors on the surface of phagocytes constitute an extremely important mechanism for the clearance of apoptotic cells. ${ }^{130}$ Patients or mice with homozygous Clq deficiency develop autoantibodies and a lupus-like syndrome apparently because of the inability to eliminate apoptotic cells effectively, which leads to an increase in the exposure of antigens to the immune system. ${ }^{129}{ }^{131}$ Mice with a targeted deletion of $\mathrm{Clq}$ show glomerulonephritis with deposits of immune complexes and apoptotic cells in the glomeruli. ${ }^{131}$

Anti-Clq antibodies can be found in a large proportion of patients, particularly those with renal disease. ${ }^{132}$ This may result in a functional deficiency of the receptor protein. It is unlikely that anti-Clq antibodies represent the primary abnormality in most patients with SLE, but they would certainly provide a mechanism for persistence of the disease and flares. ${ }^{133}$

Although bcl2 expression is increased in some lupus T cells, the overall rate of lymphocyte apoptosis is increased in SLE. Taken together with the impaired clearance mechanisms for these apoptotic materials seen in patients with SLE, this may predispose individuals to the development of antibodies against nucleosomes, which contain materials such as histones and dsDNA.

\section{ENVIRONMENTAL TRIGGERS}

Although genetic factors and the hormonal milieu may create a predisposition towards SLE, the initiation of the disease probably results from several environmental triggers and exogenous factors (table 6). Infectious agents may induce specific responses by molecular mimicry and disturb immunoregulation; diet affects the production of inflammatory mediators; toxins/drugs modify cellular responsiveness and immunogenicity of self antigens; and physical/chemical agents, such as ultraviolet (UV) light, can cause inflammation, induce cellular apoptosis, and cause tissue damage. The impingement of these environmental triggers on predisposed individuals is probably highly variable and could be a further explanation for disease heterogeneity, in addition to its alternating periods of flares and remission. 
Table 6 Environmental factors that may be relevant in the pathogenesis of systemic lupus erythematosus

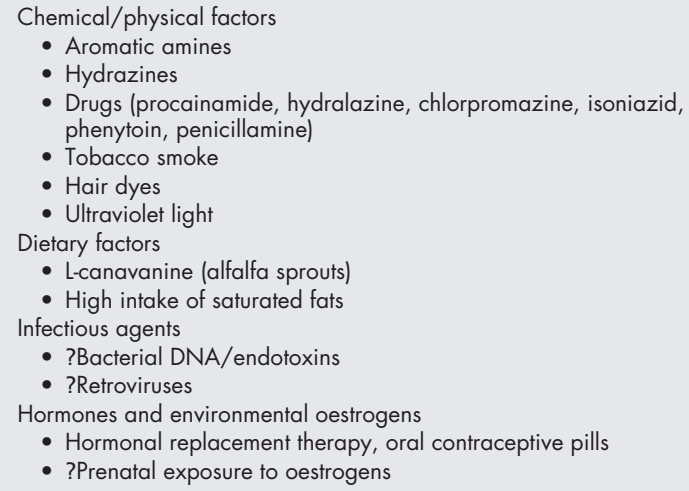

- Drugs (procainamide, hydralazine, chlorpromazine, isoniazid, phenytoin, penicillamine)

- Tobacco smoke

- Hair dyes

- Ultraviolet light

Dietary factors

- L-canavanine (alfalfa sprouts)

- High intake of saturated fats

Infectious agents

- ?Bacterial DNA/endotoxins

- ?Retroviruses

Hormones and environmental oestrogens

- Hormonal replacement therapy, oral contraceptive pills

- ?Prenatal exposure to oestrogens

\section{- Prenatal exposure to oestrogens}
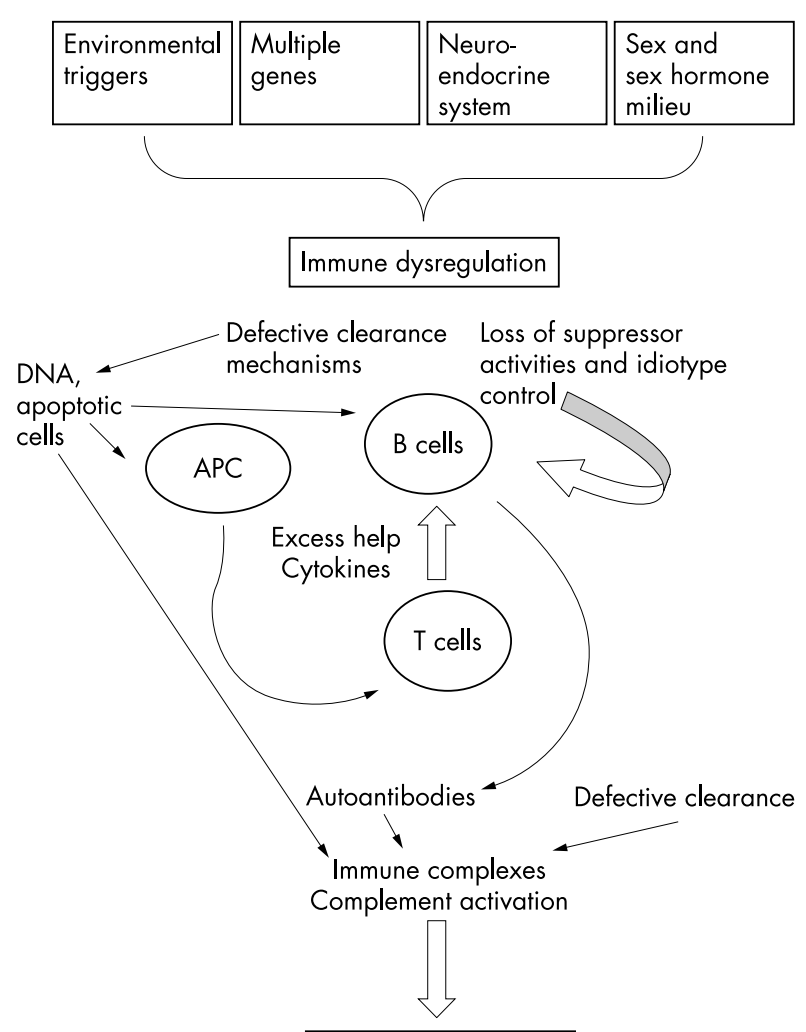

Tissue injury and damage

Figure 1 The pathogenesis of systemic lupus erythematosus. APC, antigen presenting cell.

\section{Chemical/physical factors}

Many drugs such as procainamide and hydralazine, which are aromatic amines or hydrazines, can induce a lupus-like syndrome, especially in individuals who are genetically slow acetylators. ${ }^{134}$ Both aromatic amines and hydrazines, and their derivatives, can be found in a wide variety of compounds used in agriculture and industry, and commercial applications. Hydrazine itself also occurs naturally in tobacco and tobacco smoke. Lupus-like syndromes have been reported in individuals who have ingested or have been in contact with these agents. ${ }^{135}$

Permanent hair colouring solutions contain aromatic amines that can be absorbed through the scalp. Chronic use of

\section{Take home messages}

- The patho-aetiology of systemic lupus erythematosus (SLE) probably involves complicated and multifactorial interactions among various genetic and environmental factors

- Multiple genes contribute to disease susceptibility, including genes encoding complement and other components of the immune response, in addition to major histocompatibility complex class I and II genes

- The interaction of sex, hormonal milieu (particularly oestrogenic versus androgenic activity), and the hypothalamopituitary-adrenal axis modifies this susceptibility and the clinical expression of the disease

- Defective immune regulatory mechanisms, such as the clearance of apoptotic cells and immune complexes, are important contributors to the development of SLE

- The loss of immune tolerance, increased antigenic load, excess $T$ cell help, defective $B$ cell suppression, and the shifting of T helper 1 (Th 1) to Th2 immune responses leads to $B$ cell hyperactivity and the production of pathogenic autoantibodies

- In addition, environmental factors, such as chemicals and drugs, ultraviolet light, dietary factors, viruses, and environmental oestrogen are probably required to precipitate the onset of the disease

hair dyes has been associated with the development of SLE. ${ }^{136}$ However, subsequent studies did not confirm such an association. ${ }^{135137138} \mathrm{~A}$ recent study reported only a weak association between the risk of SLE and permanent hair dyes or smoking. ${ }^{139}$

Exposure to sunlight is a well known environmental factor in the induction and exacerbation of both cutaneous and systemic lupus erythematosus. UV light, especially UVB, is an important trigger in many patients with SLE. There is good evidence that exposure of skin to UV light alters the location and/or chemistry of DNA, in addition to Ro and nRNP antigens, and probably enhances their immunogenicity. ${ }^{140}$ Recent studies have demonstrated that UV light induces the apoptosis of human keratinocytes, leading to the formation of clusters or blebs on the surface of dying cells, which contain both nuclear and cytoplasmic antigens. ${ }^{141}{ }^{142}$ This provides a mechanism for the exposure of self antigens to the immune system and provokes autoimmunity.

\section{Dietary factors and infectious agents}

Although several dietary factors and infectious agents are implicated in the pathogenesis of SLE, none of these has been consistently demonstrated in more than one study. The ingestion of alfalfa sprouts that contain L-canavanine has been linked to the development of lupus-like symptoms in several case reports. ${ }^{143}$ Infectious agents such as viruses might theoretically initiate or cause a flare in SLE by activating B cells, damaging tissues to release autoantigens, and triggering the disease by molecular mimicry. However, viral "footprints" have not been consistently demonstrated in the tissues of patients with SLE ${ }^{144}$ Thus, there is little evidence to support that one infectious agent causes SLE, although this remains a possibility and warrants further investigations.

\section{Environmental oestrogens}

The exposure of humans to environmental oestrogens is believed to increase over the years through the consumption of meat and milk products of livestock that are fed with synthetic oestrogens. ${ }^{145}{ }^{146}$ Moreover, oestrogens are increasingly used by postmenopausal women and for contraception. Chronic oestrogen exposure in prepubertal non-immune mice has been shown to influence thymic development and hence immune tolerance. ${ }^{145}$ It is therefore plausible that exposure to oestrogenic compounds during fetal life could be a potential immunological hazard. In fact, prenatal diethylstilbesterol 
exposure has been linked to autoimmune disorders, although further confirmation is needed. ${ }^{147}$ HRT and the use of OC pills have also been associated with a small increase in the risk of SLE development. ${ }^{37}{ }^{38}$ Thus, environmental oestrogens and endocrine disrupting chemicals may be important triggers for autoimmunity in susceptible individuals. The ultimate development of the disease will depend upon several factors, which include genetic background, sex, age, dose and duration of exposure, and immune status at the time of contact with these agents.

\section{SUMMARY}

The pathogenesis of SLE is summarised diagrammatically in fig l. Multiple genes confer susceptibility to disease development. Interaction of sex, hormonal milieu, the HPA axis, and defective immune regulation, such as clearance of apoptotic cells and immune complexes, modify this susceptibility. The loss of immune tolerance, increased antigenic load, excess $\mathrm{T}$ cell help, defective B cell suppression, and shifting of Thl to Th2 immune responses lead to cytokine imbalance, B cell hyperactivity, and the production of pathogenic autoantibodies. Finally, certain environmental factors are probably needed to precipitate the onset of the disease.

\section{Authors' affiliations}

C C Mok, Department of Medicine and Geriatrics, Tuen Mun Hospital, Tsing Chung Koon Road, New Territories, Hong Kong

C S Lau, Department of Medicine, Queen Mary Hospital, Hong Kong, SAR, China

\section{REFERENCES}

1 Pisetsky DS. Systemic lupus erythematosus. A. Epidemiology, pathology and pathogenesis. In: Klippel JH, ed. Primer on the rheumatic diseases, 11 th ed. Georgia, USA: Arthritis Foundation, 1997:246-51.

2 Walport MJ, Davies KA, Botto M. Clq and systemic lupus erythematosus. Immunobiology 1998;199:265-85.

3 Schur PH. Genetics of systemic lupus erythematosus. Lupus 1995;4:425-37.

4 Atkinson JP. Complement activation and complement receptors in systemic lupus erythematosus. Springer Semin Immunopathol 1986;9:179-94

5 Sullivan KE. Genetics of systemic lupus erythematosus. Clinical implications. Rheum Dis Clin North Am 2000;26:229-56.

6 Yun HR, Koh HK, Kim SS, et al. FcgammaRlla/Illa polymorphism and its association with clinical manifestations in Korean lupus patients. Lupus 2001;10:466-72.

7 Salmon JE, Millard S, Schachter LA, et al. Fc gamma RIIA alleles are heritable risk factors for lupus nephritis in African Americans. J Clin Invest 1996;97:1348-54

8 Koene HR, Kleijer M, Swaak AJ, et al. The Fc gammaRIIIA-158F allele is a risk factor for systemic lupus erythematosus. Arthritis Rheum 1998;41:1813-18.

9 Zuniga R, Ng S, Peterson MG, et al. Low-binding alleles of Fcgamma receptor types IIA and IIIA are inherited independently and are associated with systemic lupus erythematosus in Hispanic patients. Arthritis Rheum 2001;44:361-7.

10 Ip WK, Chan SY, Lau CS, et al. Association of systemic lupus erythematosus with promoter polymorphisms of the mannose-binding lectin gene. Arthritis Rheum 1998;41:1663-8.

11 Vyse TJ, Kotzin BL. Genetic susceptibility to systemic lupus erythematosus. Annu Rev Immunol 1998;16:261-92.

12 Tsao BP. An update on genetic studies of systemic lupus erythematosus. Curr Rheumatol Rep 2002;4:359-67.

13 Moser KL, Gray-McGuire C, Kelly J, et al. Confirmation of genetic linkage between human systemic lupus erythematosus and chromosome lq41. Arthritis Rheum 1999;42:1902-7.

14 Gray-McGuire C, Moser KL, Gaffney PM, et al. Genome scan of human systemic lupus erythematosus by regression modeling: evidence of linkage and epistasis at 4p16-15.2. Am J Hum Genet 2000;67: 1460-9.

15 Cervera R, Khamashta MA, Font J, et al. Systemic lupus erythematosus: clinical and immunologic patterns of disease expression in a cohort of 1,000 patients. The European Working Party on Systemic Lupus Erythematosus. Medicine (Baltimore) 1993;72:113-24.

16 Formiga F, Moga I, Pac M, et al. Mild presentation of systemic lupus erythematosus in elderly patients assessed by SLEDAI. Lupus 1999:8:462-5.

17 French MA, Hughes P. Systemic lupus erythematosus and Klinefelter's syndrome. Ann Rheum Dis 1983;42:471-3.
18 Lahita RG, Bradlow HL, Kunkel HG, et al. Alterations of estrogen metabolism in systemic lupus erythematosus. Arthritis Rheum 1979;22:1 195-8

19 Jungers $\mathbf{P}$, Nahoul K, Pelissier $C$, et al. Low plasma androgens in women with active or quiescent systemic lupus erythematosus. Arthritis Rheum 1982;25:454-7.

20 Lahita RG, Bradlow HL, Ginzler E, et al. Low plasma androgens in women with systemic lupus erythematosus. Arthritis Rheum 1987;30:241-8.

21 Lahita RG, Kunkel HG, Bradlow HL. Increased oxidation of testosterone in systemic lupus erythematosus. Arthritis Rheum 1983;26:1517-21.

22 Folomeev M, Dougados M, Beaune J, et al. Plasma sex hormones and aromatase activity in tissues of patients with systemic lupus erythematosus. Lupus 1992;1:191-5

23 Sequeira JF, Keser G, Greenstein B, et al. Systemic lupus erythematosus: sex hormones in male patients. Lupus 1993:2:315-17.

24 Mok CC, Lau CS. Profile of sex hormones in male patients with systemic lupus erythematosus. Lupus 2000;9:252-7.

25 Sthoeger ZM, Chiorazzi N, Lahita RG. Regulation of the immune response by sex hormones. I. In vitro effects of estradiol and testosterone on pokeweed mitogen-induced human B cell differentiation. J Immunol 1988;141:91-8

26 Kanda N, Tamaki K. Estrogen enhances immunoglobulin production by human peripheral blood mononuclear cells. J Allergy Clin Immunol 1999; 103:282-8

27 Kanda N, Tsuchida T, Tamaki K. Estrogen enhancement of anti-double-stranded DNA antibody and immunoglobulin $G$ production in peripheral blood mononuclear cells from patients with systemic lupus erythematosus. Arthritis Rheum 1999;42:328-37.

28 Evans MJ, MacLaughlin S, Marvin RD, et al. Estrogen decreases in vitro apoptosis of peripheral blood mononuclear cells from women with normal menstrual cycles and decreases TNF-alpha production in SLE but not in normal cultures. Clin Immunol Immunopathol 1997;82:258-62.

29 Wyle FA, Kent JR. Immunosuppression by sex steroid hormones. The effect upon PHA- and PPD-stimulated lymphocytes. Clin Exp Immunol 1977;27:407-15.

30 McMurray RW, Ndebele K, Hardy KJ, et al. 17-beta-estradiol suppresses IL-2 and IL-2 receptor. Cytokine 2001;14:324-33.

31 Rider V, Foster RT, Evans M, et al. Gender differences in autoimmune diseases: estrogen increases calcineurin expression in systemic lupus erythematosus. Clin Immunol Immunopathol 1998;89:171-80.

32 Rider V, Jones S, Evans M, et al. Estrogen increases CD4O ligand expression in T cells from women with systemic lupus erythematosus. $J$ Rheumatol 2001;28:2644-9.

33 Kanda N, Tsuchida T, Tamaki K. Testosterone inhibits immunoglobulin production by human peripheral blood mononuclear cells. Clin Exp Immunol 1996;106:410-15.

34 Kanda N, Tsuchida T, Tamaki K. Testosterone suppresses anti-DNA antibody production in peripheral blood mononuclear cells from patients with systemic lupus erythematosus. Arthritis Rheum 1997;40:1703-11.

35 Suzuki T, Suzuki N, Daynes RA, et al. Dehydroepiandrosterone enhances IL-2 production and cytotoxic effector function of human T cells. Clin Immunol Immunopathol 1991;61:202-10.

36 Suzuki T, Suzuki N, Engleman EG, et al. Low serum levels of dehydroepiandrosterone may cause deficient IL-2 production by lymphocytes in patients with systemic lupus erythematosus. Clin Exp Immunol 1995;99:251-5

37 Sanchez-Guerrero J, Liang MH, Karlson EW, et al. Postmenopausal estrogen therapy and the risk for developing systemic lupus erythematosus. Ann Intern Med 1995;122:430-3

38 Sanchez-Guerrero J, Karlson EW, Liang MH, 122. Past use of oral contraceptives and the risk of developing systemic lupus erythematosus. Arthritis Rheum 1997;40:804-8.

39 Meier CR, Sturkenboom MC, Cohen AS, et al. Postmenopausal estrogen replacement therapy and the risk of developing systemic lupus erythematosus or discoid lupus. J Rheumatol 1998;25:1515-19.

40 Rose E, Pillsbury DM. Lupus erythematosus (erythematodes) and ovarian function: observations on a possible relationship, with report of six cases. Ann Intern Med 1944;21:1022-34.

41 Mok CC, Wong RWS. Pregnancy in systemic lupus erythematosus. Postgrad Med J 2001;77:157-65.

42 Mok CC, Lau CS, Wong RWS. Use of exogenous estrogens in systemic lupus erythematosus. Semin Arthritis Rheum 2001;30:426-35.

43 Le Thi Huong D, Wechsler B, Piette JC, et al. Risks of ovulation-induction therapy in systemic lupus erythematosus. $\mathrm{Br} \mathrm{J}$ Rheumatol 1996;35:1184-6.

44 Guballa N, Sammaritano L, Schwartzman S, et al. Ovulation induction and in vitro fertilization in systemic lupus erythematosus and antiphospholipid syndrome. Arthritis Rheum 2000;43:550-6.

45 Mok CC, Lau CS, Ho CTK, et al. Do flares of systemic lupus erythematosus decline after menopause? Scand J Rheumatol 1999;28:360-5.

46 Bruce IN, Laskin CA. Sex hormones in systemic lupus erythematosus: a controversy for modern times. J Rheumatol 1997;24:1461-3.

47 Petri M. Exogenous estrogen in systemic lupus erythematosus: oral contraceptives and hormone replacement therapy. Lupus 2001;10:222-6.

48 Julkunen HA. Oral contraceptives in systemic lupus erythematosus: side effects and influence on the activity of SLE. Scand J Rheumatol 1991;20:427-33.

49 Jungers $\mathbf{P}$, Dougados $M$, Pelissier $C$, et al. Influence of oral contraceptive therapy on the activity of systemic lupus erythematosus. Arthritis Rheum 1982;25:618-23. 
50 Ho CTK, Mok CC, Lau CS, et al. Late onset systemic lupus erythematosus in southern Chinese. Ann Rheum Dis 1998;57:437-40.

51 Rood MJ, Van Der Velde EA, Ten Cate R, et al. Female sex hormones at the onset of systemic lupus erythematosus affect survival. Br J Rheumatol 1998;37:1008-10.

52 Berczi I. The immunology of prolactin. Semin Reprod Endocrinol 1992;10:196-219.

53 Matera L. Action of pituitary and lymphocyte prolactin. Neuroimmunomodulation 1997:4:171-80.

54 Cross RJ, Campbell JL, Roszman TL. Potentiation of antibody responsiveness after the transplantation of a syngeneic pituitary gland. Neuroimmunology 1989;25:29-35.

55 Walker SE, Allen SH, MCMurray RW. Prolactin and autoimmune disease. Trends Endocrinol Metab 1993;4:147-51.

56 Peeva E, Grimaldi C, Spatz L, et al. Bromocriptine restores tolerance in estrogen-treated mice. J Clin Invest 2000;106:1373-9.

57 Lavalle $C$, Loyo E, Paniagua $R$, et al. Correlation study between prolactin and androgens in male patients with systemic lupus erythematosus. J Rheumatol 1987;14:268-72.

58 Jara LJ, Gomez-Sanchez C, Silveira LH, et al. Hyperprolactinemia in systemic lupus erythematosus: association with disease activity. Am J Med Sci 1992:303:222-6.

59 Buskila D, Lorber $M$, Neumann L, et al. No correlation between prolactin levels and clinical activity in patients with systemic lupus erythematosus. J Rheumatol 1996;23:629-32.

60 Miranda JM, Prieto RE, Paniagua R, et al. Clinical significance of serum and urine prolactin levels in lupus glomerulonephritis. Lupus 1998:7:387-91.

61 Pacilio M, Migliaresi S, Meli R, et al. Elevated bioactive prolactin levels in systemic lupus erythematosus-association with disease activity. $J$ Rheumatol 2001;28:2216-21

62 Mok CC, Lau CS, Tam SC. Prolactin profile in a cohort of Chinese systemic lupus erythematosus patients. BrJ Rheumatol 1997;36:986-9.

63 Mok CC, Lau CS, Lee KW, et al. Hyperprolactinemia in males with systemic lupus erythematosus. J Rheumatol 1998;25:2357-63.

64 Ostendorf B, Fischer R, Santen R, et al. Hyperprolactinemia in systemic lupus erythematosus? Scand J Rheumatol 1996;25:97-102.

65 McMurray RW, Weidensaul D, Allen SH, et al. Efficacy of bromocriptine in an open label therapeutic trial for systemic lupus erythematosus. J Rheumatol 1995;22:2084-91

66 Walker SE, Reddy GH, Miller D, et al. Treatment of active systemic lupus erythematosus with the prolactin lowering drug, bromocriptine: comparison with hydroxychloroquine in a randomized, blinded one-year study. Arthritis Rheum 1999;42:S282 [abstract 1267].

67 Grasso G, Massai L, De Leo V, et al. The effect of LHRH and TRH on human interferon-gamma production in vivo and in vitro. Life Sci 1998;62:2005-14

68 Jacobson JD, Nisula BC, Steinberg AD. Modulation of the expression of murine lupus by gonadotropin-releasing hormone analogs. Endocrinology 1994;134:2516-23

69 Jacobson JD, Ansari MA, Kinealy M, et al. Gender-specific exacerbation of murine lupus by gonadotropin-releasing hormone potential role of $G$ alpha (q/1 1). Endocrinology 1999;140:3429-37.

70 Sternberg EM, Hill JM, Chrousos GP, et al. Inflammatory mediator-induced hypothalamic-pituitary-adrenal axis activation is defective in streptococcal cell wall arthritis-susceptible Lewis rats. Proc Natl Acad Sci U S A 1989;86:2374-8.

71 Lechner O, Dietrich H, Oliveira dos Santos A, et al. Altered circadian rhythms of the stress hormone and melatonin response in lupus-prone MRL/MP-fas(lpr) mice. J Autoimmun 2000;14:325-33.

72 Shanks N, Moore PM, Perks P, et al. Alterations in hypothalamicpituitary-adrenal function correlated with the onset of murine SLE in MRL +/+ and Ipr/Ipr mice. Brain Behav Immun 1999;13:348-60.

73 Gutierrez MA, Garcia ME, Rodriguez JA, et al. Hypothalamic-pituitaryadrenal axis function and prolactin secretion in systemic lupus erythematosus. Lupus 1998;7:404-8.

74 Tan EM, Cohen AS, Fries JF, et al. The 1982 revised criteria for the classification of systemic lupus erythematosus. Arthritis Rheum 1982;25:1271-7.

75 Vlahakos D, Foster MH, Ucci AA, et al. Murine monoclonal anti-DNA antibodies penetrate cells, bind to nuclei, and induce glomerular proliferation and proteinuria in vivo. J Am Soc Nephrol 1992;2: 1345-54.

76 Ehrenstein MR, Katz DR, Griffiths MH, et al. Human IgG anti-DNA antibodies deposit in kidneys and induce proteinuria in SCID mice. Kidney Int 1995;48:705-11.

77 Hahn BH. Antibodies to DNA. N Engl J Med 1998;338:1359-68.

78 Bootsma H, Spronk P, Derksen R, et al. Prevention of relapses in systemic lupus erythematosus. Lancet 1995;24;345:1595-9.

79 Foster MH, Cizman B, Madaio MP. Nephritogenic autoantibodies in systemic lupus erythematosus: immunochemical properties, mechanisms of immune deposition, and genetic origins. Lab Invest 1993;69:494507

80 van Bruggen $M C$, Kramers C, Walgreen B, et al. Nucleosomes and histones are present in glomerular deposits in human lupus nephritis. Nephrol Dial Transplant 1997;12:57-66.

81 James JA, Gross T, Scofield RH, et al. Immunoglobulin epitope spreading and autoimmune disease after peptide immunization: $\mathrm{Sm}$ $B / B^{\prime}$-derived PPPGMRPP and PPPGIRGP induce spliceosome autoimmunity. J Exp Med 1995;181:453-61.

82 Klinman DM, Shirai A, Ishigatsubo Y, et al. Quantitation of IgM- and lgG-secreting B cells in the peripheral blood of patients with systemic lupus erythematosus. Arthritis Rheum 1991;34:1404-10.
83 Liossis SN, Kovacs B, Dennis $G$, et al. B cells from patients with systemic lupus erythematosus display abnormal antigen receptor-mediated early signal transduction events. J Clin Invest 1996;98:2549-57.

84 Linker-Israeli $M$, Deans RJ, Wallace DJ, et al. Elevated levels of endogenous IL-6 in systemic lupus erythematosus. A putative role in pathogenesis. J Immunol 1991;147:117-23.

85 Monneaux F, Muller S. Epitope spreading in systemic lupus erythematosus: identification of triggering peptide sequences. Arthritis Rheum 2002;46:1430-8.

86 Bakke AC, Kirkland PA, Kitridou RC, et al. T lymphocyte subsets in systemic lupus erythematosus. Correlations with corticosteroid therapy and disease activity. Arthritis Rheum 1983:26:745-50.

87 Linker-Israeli $M$, Quismorio FP Jr, Horwitz DA. CD8+ lymphocytes from patients with systemic lupus erythematosus sustain, rather than suppress, spontaneous polyclonal lgG production and synergize with $\mathrm{CD} 4+$ cells to support autoantibody synthesis. Arthritis Rheum 1990;33:1216-25.

88 Portales-Perez D, Gonzalez-Amaro R, Abud-Mendoza C, et al. Abnormalities in CD69 expression, cytosolic $\mathrm{pH}$ and $\mathrm{Ca} 2+$ during activation of lymphocytes from patients with systemic lupus erythematosus. Lupus 1997;6:48-56.

89 Fernandez-Gutierrez B, de Miguel S, Morado C, et al. Defective early $T$ and T-dependent $B$ cell activation in systemic lupus erythematosus. Lupus 1998;7:314-22.

90 Horwitz DA, Garrett MA. Lymphocyte reactivity to mitogens in subjects with systemic lupus erythematosus, rheumatoid arthritis and scleroderma. Clin Exp Immunol 1977;27:92-9.

91 Alcocer-Varela J, Alarcon-Segovia D. Decreased production of and response to interleukin-2 by cultured lymphocytes from patients with systemic lupus erythematosus. J Clin Invest 1982;69:1388-92.

92 Warrington RJ. Interleukin-2 abnormalities in systemic lupus erythematosus and rheumatoid arthritis. A role for overproduction of interleukin-2 in human autoimmunity? I Rheumatol 1988;15:616-20.

93 Linker-Israeli $M$, Bakke AC, Kitridou RC, et al. Defective production of interleukin 1 and interleukin 2 in patients with systemic lupus erythematosus (SLE). J Immunol 1983;130:2651-5.

94 Garcia-Cozar FJ, Molina IJ, Cuadrado M, et al. Defective B7 expression on antigen-presenting cells underlying T cell activation abnormalities in systemic lupus erythematosus (SLE) patients. Clin Exp Immunol 1996;104:72-9.

95 Lauwerys BR, Houssiau FA. Cytokines: clues to the pathogenesis of SLE. Lupus 1998;7:211-13.

96 Horwitz DA, Wang H, Gray JD. Cytokine gene profile in circulating blood mononuclear cells from patients with systemic lupus erythematosus: increased interleukin-2 but not interleukin-4 mRNA. Lupus 1994;3:423-8.

97 Murakawa Y, Sakane T. Deficient phytohemagglutinin-induced interleukin-2 activity in patients with inactive systemic lupus erythematosus is correctable by the addition of phorbol myristate acetate. Arthritis Rheum 1988;31:826-33.

98 Llorente L, Richaud-Patin Y, Wijdenes J, et al. Spontaneous production of interleukin-10 by B lymphocytes and monocytes in systemic lupus erythematosus. Eur Cytokine Netw 1993;4:42 1-7.

99 Llorente L, Richaud-Patin Y, Fior R, et al. In vivo production of interleukin-10 by non-T cells in rheumatoid arthritis, Sjogren's syndrome, and systemic lupus erythematosus. A potential mechanism of $B$ lymphocyte hyperactivity and autoimmunity. Arthritis Rheum 1994;37: 1647-55.

100 Csiszar A, Nagy G, Gergely P, et al. Increased interferon-gamma (IFN-gamma), IL-10 and decreased IL-4 mRNA expression in peripheral blood mononuclear cells (PBMC) from patients with systemic lupus erythematosus (SLE). Clin Exp Immunol 2000;1 22:464-70.

101 Houssiau FA, Lefebvre C, Vanden Berghe M, et al. Serum interleukin 10 titers in systemic lupus erythematosus reflect disease activity. Lupus 1995;4:393-5

102 Park YB, Lee SK, Kim DS, et al. Elevated interleukin-10 levels correlated with disease activity in systemic lupus erythematosus. Clin Exp Rheumatol 1998; 16:283-8

103 Grondal G, Gunnarsson I, Ronnelid J, et al. Cytokine production, serum levels and disease activity in systemic lupus erythematosus. Clin Exp Rheumatol 2000:18:565-70.

104 Hagiwara E, Gourley MF, Lee S, et al. Disease severity in patients with systemic lupus erythematosus correlates with an increased ratio of interleukin-10 : interferon-gamma-secreting cells in the peripheral blood. Arthritis Rheum 1996;39:379-85.

105 Lauwerys BR, Garot N, Renauld JC, et al. Interleukin-10 blockade corrects impaired in vitro cellular immune responses of systemic lupus erythematosus patients. Arthritis Rheum 2000;43:1976-81.

106 Tyrrell-Price J, Lydyard PM, Isenberg DA. The effect of interleukin-10 and of interleukin-12 on the in vitro production of anti-double-stranded DNA antibodies from patients with systemic lupus erythematosus. Clin Exp Immunol 2001;124:1 18-25.

107 Trinchieri G. Interleukin-12: a cytokine produced by antigen-presenting cells with immunoregulatory functions in the generation of T-helper cells type 1 and cytotoxic lymphocytes. Blood 1994;84:4008-27.

108 Horwitz DA, Gray JD, Behrendsen SC, et al. Decreased production of interleukin-12 and other Th 1-type cytokines in patients with recent-onse systemic lupus erythematosus. Arthritis Rheum 1998:41:838-44.

109 Liu TF, Jones BM. Impaired production of IL-12 in systemic lupus erythematosus. I. Excessive production of IL-10 suppresses production of IL-12 by monocytes. Cytokine 1998;10:140-7.

110 Liu TF, Jones BM. Impairment of IL-12 production in SLE is due to defective monocytes, not B cells. Immunol Lett 1997;56:314.

111 Houssiau FA, Mascart-Lemone F, Stevens M, et al. IL-12 inhibits in vitro immunoglobulin production by human lupus peripheral blood mononuclear cells (PBMC). Clin Exp Immunol 1997; 108:375-80. 
112 Mir A, Porteu F, Levy M, et al. C3b receptor (CR I) on phagocytic cells from SLE patients: analysis of the defect and familial study. Clin Exp Immunol 1988;73:46 1-6.

113 Kiss E, Csipo I, Cohen JH, et al. CRI density polymorphism and expression on erythrocytes of patients with systemic lupus erythematosus. Autoimmunity 1996;25:53-8.

114 Dijstelbloem HM, Bijl M, Fijnheer R, et al. Fcgamma receptor polymorphisms in systemic lupus erythematosus: association with disease and in vivo clearance of immune complexes. Arthritis Rheum 2000;43:2793-800

115 Zuniga R, Ng S, Peterson MG, et al. Low-binding alleles of Fcgamma receptor types IIA and IIIA are inherited independently and are associated with systemic lupus erythematosus in Hispanic patients. Arthritis Rheum 2001;44:361-7.

116 Herrmann M, Voll RE, Zoller OM, et al. Impaired phagocytosis of apoptotic cell material by monocyte-derived macrophages from patients with systemic lupus erythematosus. Arthritis Rheum 1998;41:1241-50.

117 Mohan C, Adams S, Stanik V, et al. Nucleosome: a major immunogen for pathogenic autoantibody-inducing T cells of lupus. J Exp Med 1993;177:1367-81.

118 Filaci G, Bacilieri S, Fravega M, et al. Impairment of CD8+ T suppressor cell function in patients with active systemic lupus erythematosus. J Immunol 2001;166:6452-7.

119 Sherer Y, Shoenfeld Y. Idiotypic network dysregulation: a common etiopathogenesis of diverse autoimmune diseases. Appl Biochem Biotechnol 2000;83:155-62.

120 Suzuki N, Ichino M, Mihara S, et al. Inhibition of Fas/Fas ligand-mediated apoptotic cell death of lymphocytes in vitro by circulating anti-Fas ligand autoantibodies in patients with systemic lupus erythematosus. Arthritis Rheum 1998;41:344-53.

121 Theofilopoulos AN, Dixon FJ. Etiopathogenesis of murine SLE. Immunol $\operatorname{Rev} 1981 ; 55: 179-216$.

122 Takahashi T, Tanaka M, Brannan Cl, et al. Generalized lymphoproliferative disease in mice, caused by a point mutation in the Fas ligand. Cell 1994;76:969-76

123 McNally J, Yoo DH, Drappa J, et al. Fas ligand expression and function in systemic lupus erythematosus. J Immunol 1997;159:4628-36.

124 Wu J, Wilson J, He J, et al. Fas ligand mutation in a patient with systemic lupus erythematosus and lymphoproliferative disease. J Clin Invest 1996;98:1107-13.

125 Emlen W, Niebur J, Kadera R. Accelerated in vitro apoptosis of lymphocytes from patients with systemic lupus erythematosus. J Immunol 1994; 152:3685-92.

126 Courtney PA, Crockard AD, Williamson K, et al. Lymphocyte apoptosis in systemic lupus erythematosus: relationships with Fas expression, serum soluble Fas and disease activity. Lupus 1999;8:508-13.

127 Shoshan Y, Shapira I, Toubi E, et al. Accelerated Fas-mediated apoptosis of monocytes and maturing macrophages from patients with systemic lupus erythematosus: relevance to in vitro impairment of interaction with iC3b-opsonized apoptotic cells. J Immunol 2001;167:5963-69.

128 Baumann I, Kolowos W, Voll RE, et al. Impaired uptake of apoptotic cells into tingible body macrophages in germinal centers of patients with systemic lupus erythematosus. Arthritis Rheum 2002;46:191-201.
129 Walport MJ, Davies KA, Botto M. Clq and systemic lupus erythematosus. Immunobiology 1998;199:265-85.

130 Korb LC, Ahearn JM. Clq binds directly and specifically to surface blebs of apoptotic human keratinocytes: complement deficiency and systemic lupus erythematosus revisited. J Immunol 1997;158:4525-8.

131 Botto $M$, Dell'Agnola C, Bygrave AE, et al. Homozygous Clq deficiency causes glomerulonephritis associated with multiple apoptotic bodies. Nat Genet 1998;19:56-9.

132 Haseley LA, Wisnieski JJ, Denburg MR, et al. Antibodies to Clq in systemic lupus erythematosus: characteristics and relation to $\mathrm{Fc}$ gamma RIIA alleles. Kidney Int 1997;52:1375-80.

133 Salmon M, Gordon C. The role of apoptosis in systemic lupus erythematosus. Rheumatology (Oxford) 1999:38:1177-83.

134 Adams LE, Mongey AB. Role of genetic factors in drug-related autoimmunity. Lupus 1994;3:443-7.

135 Reidenberg MM, Drayer DE, Lorenzo B, et al. Acetylation phenotypes and environmental chemical exposure of people with idiopathic systemic lupus erythematosus. Arthritis Rheum 1993;36:971-3.

136 Freni-Titulaer LW, Kelley DB, Grow AG, et al. Connective tissue disease in southeastern Georgia: a case-control study of etiologic factors. Am J Epidemiol 1989;130:404-9.

137 Petri M, Allbritton J. Hair product use in systemic lupus erythematosus. A case-control study. Arthritis Rheum 1992;35:625-9.

138 Sanchez-Guerrero J, Karlson EW, Colditz GA, et al. Hair dye use and the risk of developing systemic lupus erythematosus. Arthritis Rheum 1996;39:657-62.

139 Cooper GS, Dooley MA, Treadwell EL, et al. Smoking and use of hair treatments in relation to risk of developing systemic lupus erythematosus. J Rheumatol 2001;28:2653-6.

140 Furukawa $F$, Kashihara-Sawami M, Lyons MB, et al. Binding of antibodies to the extractable nuclear antigens SS-A/Ro and SS-B/La is induced on the surface of human keratinocytes by ultraviolet light (UVL): implications for the pathogenesis of photosensitive cutaneous lupus. J Invest Dermatol 1990;94:77-85.

141 Casciola-Rosen L, Rosen A. Ultraviolet light-induced keratinocyte apoptosis: a potential mechanism for the induction of skin lesions and autoantibody production in LE. Lupus 1997;6:175-80.

142 Casciola-Rosen L, Andrade F, Ulanet D, et al. Cleavage by granzyme B is strongly predictive of autoantigen status: implications for initiation of autoimmunity. J Exp Med 1999:190:815-26.

143 Prete PE. The mechanism of action of L-canavanine in inducing autoimmune phenomena. Arthritis Rheum 1985;28:1 198-200.

144 Herrmann M, Hagenhofer M, Kalden JR. Retroviruses and systemic lupus erythematosus. Immunol Rev 1996:152:145-56.

145 Ahmed SA, Hissong BD, Verthelyi D, et al. Gender and risk of autoimmune diseases: possible role of estrogenic compounds. Environ Health Perspect 1999;107(suppl 5):681-6.

146 Marselos M, Tomatis L. Diethylstilboestrol. II: Pharmacology, toxicology and carcinogenicity in experimental animals. Eur J Cancer 1993;29A: 149-55.

147 Noller KL, Blair PB, O'Brien PC, et al. Increased occurrence of autoimmune disease among women exposed in utero to diethylstilbestrol. Fertil Steril 1988;49:1080-2. 